\title{
TESTING ADAPTIVE MARKET HYPOTHESIS IN GLOBAL ISLAMIC STOCK MARKETS: EVIDENCE FROM MARKOV-SWITCHING ADF TEST
}

Mehmet Fatih BUĞANa

Nüket KIRCI ÇEVIKc
Emrah İsmail ÇEVIK ${ }^{\mathrm{b}}$

Durmuş Çağrı YILDIRIMd

\begin{abstract}
Although market efficiency has been extensively examined in the literature, the studies generally focus on conventional stock markets. Since market efficiency is related to a well-functioning market, it is of great importance for the efficient allocation of resources and also providing sustainable economic growth. Market efficiency is not only important for conventional stock markets but also for the Islamic stock market as the Islamic stock markets are gaining prominence. An increase in the scope of Islamic markets worldwide creates the motivation for investigating the efficiency of Islamic stock markets. Hence there is a growing interest in Islamic stock markets. With a limited number of studies that analyze the efficient market hypothesis in Islamic stock markets, this paper aims to examine market efficiency in the global Islamic stock markets via MarkovSwitching Augmented Dickey-Fuller (MS-ADF) test. The linear unit root test result shows that the global Islamic stock market indices exhibit random walk properties that are consistent with the Efficient Market Hypothesis. On the other hand, nonlinear test results suggest global Islamic stock markets exhibit twostate regime-switching characteristics. The MS-ADF test results indicate that the world and developed Islamic stock markets are stationary only in the high volatility regime and this finding supports the Adaptive Market Hypothesis. However, the emerging Islamic stock market is found to be stationary in both regimes that are contradictory for weak-form efficiency.
\end{abstract}

Keywords: Islamic Economy, Efficient Market Hypothesis, Adaptive Market Hypothesis, Islamic Stock Markets, Markov-Switching ADF

\footnotetext{
a Asst. Prof., Gaziantep University, mfbugan@gantep.edu.tr

b Assoc. Prof., Namık Kemal University, eicevik@nku.edu.tr

c Assoc. Prof., Namık Kemal University, nkcevik@nku.edu.tr

d Prof., Namık Kemal University, dcyildirim@nku.edu.tr
} 


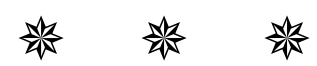

\section{GLOBAL İSLAMI PAY PIYASALARINDA ADAPTIF PIYASA HIPOTEZININ TEST EDILMESİ: MARKOV-SWITCHING ADF TESTI}

Finansal piyasaların etkinliği literatürde geniş bir şekilde incelenmesine rağmen, söz konusu çalışmalar genellikle konvansiyonel borsalara odaklanmıştır. Piyasa etkinliği, iyi işleyen bir piyasayla ilgili olduğundan, kaynakların verimli bir şekilde tahsisi ve aynı zamanda sürdürülebilir ekonomik büyüme sağlaması açısından büyük önem taşımaktadır. İslami piyasalara olan ilgi giderek arttığından, piyasa etkinliği sadece konvansiyonel borsalar için değil, İslami piyasalar için de oldukça önemlidir. Dünya genelinde İslami piyasalarının kapsamının genişlemesi, söz konusu piyasaların etkinliğini araştırmaya yönelik ayrıca bir motivasyon sağlamaktadır. İslami pay piyasalarında etkin piyasa hipotezini analiz eden sınırlı sayıdaki çalışmalar ile beraber bu makale, MarkovSwitching Augmented Dickey-Fuller (MS-ADF) testi ile global İslami pay piyasalarında piyasa etkinliğini incelemeyi amaçlamaktadır. Doğrusal birim kök testi sonucu, global İslami pay piyasası endekslerinin Etkin Piyasa Hipotezi ile tutarlı olan rassal yürüyüş (random walk) özelliği sergilediğini göstermektedir. Öte yandan, doğrusal olmayan test sonuçları, global İslami pay piyasalarının iki durumlu rejim değişim özelliği sergilediğini göstermektedir. MS-ADF test sonuçları, global ve gelişmiş İslami pay piyasalarının sadece yüksek volatilite rejiminde durağan olduğunu göstermektedir ve bu bulgu, Adaptif Piyasa Hipotezini desteklemektedir. Bununla birlikte, gelişmekte olan İslami pay piyasaları, zayıf formda etkin piyasa hipotezi ile çelişkili bir biçimde her iki rejimde de durağan bulunmuştur.

[Geniş Türkçe öz makalenin sonunda yer almaktadır.]

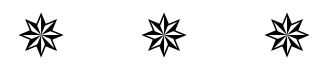

\section{Introduction}

The Efficient Market Hypothesis (EMH) formulated by Fama (1970) suggests all available and relevant information is reflected in stock prices. The EMH emphasizes the importance of information flows where incremental information will be reflected in stock prices, hence investors cannot obtain abnormal returns relative to a passive market strategy. According to the weak-form efficiency, stock prices embed all information contained in past prices. With the semi-strong market efficiency, prices reflect all publicly available information, whereas the strong form of the EMH implies prices reflect all public and private information. After Fama and French (1988a, b), Lo and MacKinlay (1988), and Poterba and Summers (1988), there has been an extensive literature that examines the feasibility 
of the EMH in conventional stocks markets in addition to the related financial models that include portfolio optimization, the Capital Asset Pricing Model, the Arbitrage Pricing Theory, and option pricing models.

A critical underlying assumption of the EMH is that investors act rationally in their investment decisions. On the other hand, a large number of studies find evidence in favor of anomalies in the stock markets, predictability of returns in some cases, and limited rationality of investors in contradiction of the EMH. Moreover, several studies in psychology and experimental economics focused on deviations from the rationality of investors and as a result, many biases and heuristics have been identified. These results led to the revival of the behavioral finance approach, where investors are not always acting rationally in their investment decisions.

At this point, the Adaptive Market Hypothesis (AMH) suggested by Lo (2004) comes to the fore providing a bridge between EMH and behavioral finance. Lo (2004) revisited the notion of bounded rationality introduced by Simon (1955) from an evolutionary perspective. This perspective implies behaviors evolve by natural selection and the latter indicates behaviors that may be individually sub-optimal but are optimal from a population perspective. Accordingly, behaviors may not be considered in a vacuum, but are highly context-dependent. Lo (2005) put forth the fundamentals of the $\mathrm{AMH}$ as follows: (i) self-interest characterizes individual behavior; (ii) individuals are not free of mistakes; (iii) the environment is competitive; iv) competition forces individuals to learn and adapt; (v) natural selection shapes aggregate market outcomes; (vi) evolution determines eventual market dynamics. According to AMH, the efficiency of markets is not a binary outcome of all or nothing but varies continuously over time and across markets (Lo 2005: p.3). This statement has two important consequences. First, external factors characterizing the market environment, such as the number of competitors in the market, the size of extant profit opportunities, and the adaptability of market participants, all contribute to the degree of market efficiency. Second, the ever-evolving market conditions (cycles, bubbles, crashes, etc.) produce some episodes of relative predictability. Despite the fact that the AMH is still in its relative infancy, it has several concrete implications: (i) the risk-reward opportunities change over time; (ii) arbitrage opportunities arise occasionally; (iii) investment strategies may be fine-tuned according to change due to changing business conditions; (iv) the key to survival is an adaptation to changing market conditions.

As mentioned above, many models in finance are based on market 
efficiency and market efficiency has important implications on investment strategies. Not only is market efficiency important from a resource allocation perspective but it is also of interest to investors, academics, and regulatory authorities and there is well-documented literature examining the EMH for conventional stock markets. In this context, it is also of interest to examine market efficiency for the Islamic stock market because such markets offer alternatives for investors with religious sensibilities and have been growing at a rapid rate recently. Hence, there is a growing literature that investigates the efficiency of the Islamic stock markets (Alvarez-Diaz et al., 2014; Gupta et al., 2014; Jawadi et al., 2015; Aloui et al., 2016; Bouoiyour et al., 2018; Yücel, A. G. \& Köseoğlu, A., 2020).

There are additional factors that make investigating EMH for the Islamic financial markets important because the way Islamic portfolios are formed might contribute to some level of predictability. It is known that the two-stage shariah screening results in low-leverage, illiquidity, low capital market, asset-based, and less diversified portfolios, and this is prone to improved predictability of Islamic stock prices. Alvarez-Diaz et al. (2014) indicated that the Islamic markets are more predictable due to these characteristic features, whereas Gupta et al. (2014) and Ali et al. (2018) provided the opposite empirical evidence. Jawadi et al. (2015) found out Islamic stock markets seem to be less efficient than developed Islamic markets, suggesting investment opportunities and diversification benefits.

The study aims to investigate the efficient and adaptive market hypotheses for Islamic stock markets by employing a nonlinear unit root test (MS-ADF). The issue of nonlinear unit root test is germane because Nasr et al. (2016) and Cevik and Bugan (2018) found evidence in favor of nonlinearity in Islamic stock markets. It is well known that linear unit root tests have low power to reject the null hypothesis of a unit root in case of nonlinearity. There are two competing nonlinear modeling techniques; threshold models and the Markov-Switching model to address the issue. On the other hand, Maitland-Smith and Brooks (1999) found out that MarkovSwitching models outperform threshold models when the variables under study are non-stationary. Similarly, by using Monte Carlo simulations, Kruse et al. (2012) found that the MS-ADF unit root test has higher power than threshold unit root tests. To the end, we employ the MS-ADF unit root test to examine the validity of the AMH in the Islamic stock markets. To the best of our knowledge, this study is the first attempt to investigate regime|428| dependent weak-form efficiency in the global Islamic stock markets via the MS-ADF test. The MS-ADF test also allows us to examine the validity of EMH 
and AMH simultaneously.

The remainder of the paper is organized as follows. The next section presents the literature review. Section 3 presents the econometric methodology. In Section 4, we report the empirical results and concludes.

\section{A. Literature Review}

Numerous previous studies have focused on market efficiency testing several versions of the EMH. Some focus on market efficiency in the energy markets (Khediri \& Charfeddine, 2015; Ghazani \& Ebrahimi, 2019), bond markets (Charfeddine et al., 2018), stock markets (Alvarez-Ramirez et al., 2012; Urquhart \& Hudson, 2013; Hiremath \& Kumari, 2014; Rodriguez et al., 2014; Xiong et al., 2019), commodities markets (Shahid et al., 2019a), cryptocurrencies (Khursheed et al., 2020) and foreign exchange markets (Charles et al., 2012) within the framework of AMH.

To examine the weak-form EMH of spot and future energy markets, Khediri \& Charfeddine (2015) used rolling samples and the wild bootstrap Variance Ratio tests. They found that the efficiency of energy markets is not uniform over time which supports the adaptive market hypothesis. Ghazani \& Ebrahimi (2019) applied the automatic portmanteau and generalized spectral tests to investigate the validity of the EMH or AMH for daily returns on the three benchmark crude oils (Brent, WTI, and OPEC) over the period is from 2003 to 2018. They find that market conditions for WTI and Brent are consistent with the implication of the AMH, but not OPEC basket data. Using a time-varying approach to examine bond market efficiency in the U.S., the U.K., South Africa, and India, Charfeddine et al. (2018) found evidence in favor of the AMH in characterizing the behavior of government bond returns. Likewise, Shahid et al. (2019a) hold a similar view for the behavior of commodity markets after they examine commodity (gold, silver, and metal) market efficiency from 1992 to 2016 via linear time series models (variance ratio test, runs test, and autocorrelation test). Charles et al. (2012) evaluate time-varying return predictability of major foreign exchange rates over the period from 1974 to 2009 by applying the wild bootstrap automatic variance ratio test, generalized spectral test, and Dominguez-Lobato consistent tests. Their findings suggest that the return predictability of foreign exchange rates varies over time depending on market conditions. Khursheed et al. (2020) examined the AMH in cryptocurrency markets (such as bitcoin, Monaro, litecoin, and steller) using generalized spectral, Dominguez-Lobato, and the automatic portmanteau test for the period of 2014-2018 and concluded that the predictability varies over time. 
Mehmet Fatih BUĞAN, Emrah İsmail ÇEVİK \& Nüket KIRCI ÇEVIK \& D. Çağrı YILDIRIM

There is a growing literature that investigates the AMH in conventional stock markets. Alvarez-Ramirez et al. (2012) analyzed the time series of the Dow Jones Industrial Average (DJIA) from 1929 to 2012 via entropy concepts to examine market efficiency within the AMH framework. They concluded that market efficiency varies continuously over time and across markets, which is consistent with the AMH. To examine whether the AMH is adequate in explaining the behavior of the stock returns in developed stock markets (U.S., U.K., and Japan), Urquhart and Hudson (2013) used a range of linear and nonlinear tests. They analyzed the daily prices of three long-standing stock market indices, the DJIA, FT30, and TOPIX, and concluded that the AMH provides a better description of the behavior of stock markets. Similarly, Hiremath and Kumari (2014) found evidence in favor of the AMH in the Indian stock market. Rodriguez et al. (2014) studied the random walk hypothesis for the U.S. stock market with a daily frequency of DJIA using data from 1929 to 2012. The detrended fluctuation analysis (DFA) implemented over a rolling window method indicates that the stock market responds to changing conditions, from economics to social shocks, which is in line with the adaptive market hypothesis. For the Chinese stock market, Xiong et al. (2019) examined the validity of the four calendar effects (Monday, January, turn of the month, and Chinese Lunar New Year) over time. They concluded that the AMH gives a better explanation for market dynamics in the Chinese stock market.

The studies that focus on Islamic stock markets generally examine the weak form of efficiency. However, Charles et al. (2017) investigated the conventional and Islamic stock market in terms of the AMH framework. However, Al-Khazali and Mirzaei (2017) and Shahid et al. (2019b) focused on anomalies in Islamic stock markets. Charles et al. (2017) explored the degree of return predictability of Dow Jones Islamic and conventional size and sector-indices from 1996 to 2013 by using the automatic portmanteau and variance ratio tests. Their results showed that all return series could be predictable in several sub-periods and this finding provides evidence in favor of the AMH. Al-Khazali and Mirzaei (2017) investigated the timevarying properties of calendar anomalies (Monday, weekly, and January effects) in eight Dow Jones Islamic indices for the periods of 1996-2015. They employed the stochastic dominance analysis and found the calendar anomalies exhibit time-varying behavior and this result is consistent with the AMH. Shahid et al. (2019b) examine the behavior of the Ramadan effect in the emerging market of Pakistan. The study included a sample of 107 companies from January 1996 to December 2015. They concluded that the 
Ramadan effect evolves which is consistent with AMH.

Taken together, these studies support the notion that the AMH better describes the behavior of stock markets than the EMH.

\section{B. Econometric Framework}

A unit root in the stock prices is closely related to the weak-form market efficiency. Therefore, we start with the following the augmented Dickey and Fuller (ADF) unit root test suggested by Dickey and Fuller (1979):

$$
\Delta p_{t}=\mu+\rho p_{t-1}+\sum_{k=1}^{l} \alpha_{k} \Delta p_{t-k}+\varepsilon_{t}
$$

where $\Delta p_{t}$ is the first difference of the Islamic stock market index and $\varepsilon_{t}$ is the innovation process. The null hypothesis of nonstationary $(\rho=0)$ is tested against the alternative hypothesis of a stationary process $(\rho<0)$ by using a $t$-test for the autoregressive parameters, where the latter has a nonstandard distribution under the null hypothesis.

$\mathrm{ADF}$ unit root test is restrictive in practice because several factors such as structural breaks and market frictions, etc., may cause the stock market to exhibit regime-switching properties. Empirical studies show that the ADF test exhibits low performance to reject the null of nonstationarity when the series exhibits regime-switching properties (Nelson et al., 2001; Kanas and Genius, 2005; Holmes, 2010). Therefore, the MS-ADF unit root test suggested by Hall et al. (1999) can be used: 1

$$
\begin{aligned}
& \quad \Delta p_{t}=\mu\left(s_{t}\right)+\rho\left(s_{t}\right) p_{t-1}+\sum_{k=1}^{l} \alpha_{k}\left(s_{t}\right) \Delta p_{t-k}+\varepsilon_{t} \\
& \varepsilon_{t} \sim \operatorname{NID}\left(0, \sum\left(\mathrm{s}_{\mathrm{t}}\right)\right)
\end{aligned}
$$

where $s_{t}$ is the state variable, $\mu\left(s_{t}\right), \rho\left(s_{t}\right)$, and $\alpha\left(s_{t}\right)$ are regimedependent parameters and $\varepsilon_{t}$ is the innovation process. It is assumed that the stock market index pursues a two-regime Markov process and the unobserved regime variable, $s_{t}$, evolves according to a first-order MarkovSwitching process described in Hamilton (1994). We estimate Equation (2) via the maximum likelihood method based on the Expectation-Maximization (EM) algorithm discussed in Hamilton (1994). In the MS-ADF test, the null hypothesis of stationarity ( $\rho=0$ for $s_{t}=1$ and 2) is tested against the alternative of non-stationarity $\left(\rho<0\right.$ for $s_{t}=1$ and 2$)$.

Note that we allow the volatility of stock price to switch across the

1 We also considered using the MS-ADF test with the deterministic trend but this model did not have a better fit. 
regimes. Shi (2013) showed that the MS-ADF test results are very sensitive to error variance specification and allowing the regime-dependent error variance substantially increases the power of the test. However, the MS-ADF unit root test provides a regime-dependent test, the results of which allow us testing both EMH and AMH simultaneously.

Nasr et al. (2016) and Cevik and Bugan (2018) showed that the Islamic stock market index exhibits regime-switching properties; as such, we also investigate the presence of nonlinearity in the Islamic stock market index using the Markov-Switching specific test. Although there has been extensive literature for the Markov-Switching specific linearity tests, most are computationally intensive (See Hansen, 1992; Garcia, 1998; Cho and White, 2007 and Carrasco et al., 2009). Di Sanzo (2009) proposed a testing methodology that depends on a bootstrap resampling procedure to determine whether Markov-Switching models better describe the data. Monte Carlo simulation results indicated that the testing methodology outperforms the test suggested by Hansen (1992) and Carrosco et al. (2009). Di Sanzo (2009) indicated that this testing procedure can be easily computed and gives consistent results when the sample size is small.

The bootstrap based LR test consists of four steps (Cevik et al., 2020). The standardized residuals from the linear model are obtained in the first step. The second step requires the calculation of the LR test as follows:

$$
L R=2\left[L(\theta)-L\left(\theta_{r}\right)\right]
$$

where $L(\theta)$ and $L\left(\theta_{r}\right)$ are the log-likelihood values for the MarkovSwitching model and the linear model respectively and $r$ represents the number of restrictions. The third step consists of creating bootstrap sample and error terms via estimated parameters of the linear model. In the last step, we calculate the $L R^{*}$ test statistic by using the bootstrap sample, and steps 3 and 4 are repeated 499 times. $^{2}$ In this way, we obtain the distribution of the $L R^{*} \quad$ statistic and compute the bootstrap $p$-value as $p_{B}=\operatorname{card}\left(L R^{*} \geq L R\right) / 499$ where the bootstrap $p$-value indicates the fraction of $L R^{*}$ values which are greater than the observed value, $L R$.

We follow Kanas and Genius (2005) and use Monte Carlo simulations to obtain critical values since the distribution of the MS-ADF test does not follow the standard distribution. As in Kansas and Genius (2005) and Cevik and Dibooglu (2013), we generate the p-values for the rejection of the null

${ }^{2}$ As in Di Sanzo (2009), the numbers of repetitions are chosen as 499 times 
hypothesis by using 1000 repetitions.

\section{Data and Empirical Results}

We use daily data for three major Islamic stock markets; world (Dow Jones Islamic Market Index- DJIM), developed (Dow Jones Islamic Developed Markets Index-DJID), and emerging (Dow Jones Islamic Market World Emerging Markets Index-DJIE) that are obtained from DataStream from 1996 to 2019. The total number of observations is 6261 .

The descriptive statistics in Table 1 show that all stock market indices provide a positive mean return during the sample period. The highest mean returns are obtained from the DJID market, whereas the DJIE market provides the lowest mean return during the sample. According to standard deviations, the DJIE has the highest volatility. Skewness and kurtosis values suggest that all return series have leptokurtic distribution. The null hypothesis of normality is rejected at the $1 \%$ significance level for all return series according to the Jarque-Bera test.

Table 1: Descriptive Statistics

\begin{tabular}{|l|l|l|l|}
\hline & DJIW & DJID & DJIE \\
\hline $\boldsymbol{n}$ & 6261 & 6261 & 6261 \\
\hline Mean & 0.025 & 0.026 & 0.016 \\
\hline Std. Dev. & 0.979 & 1.018 & 1.243 \\
\hline Skewness & -0.382 & -0.370 & -0.359 \\
\hline Kurtosis & 10.275 & 13.030 & 9.389 \\
\hline Jarque-Bera & $13957.6[0.000]$ & $26388.9[0.000]$ & $10784.76[0.000]$ \\
\hline
\end{tabular}

Notes: The figures in square brackets show the probability ( $p$-values) of rejecting the null hypothesis.

The Pearson correlation analysis results that are presented in Table 2 show that the correlation coefficients for the return series are high and statistically significant at the $1 \%$ level. Also, the highest correlation coefficient occurs between the world and developed Islamic stock market where the correlation coefficient is $97 \%$.

Table 2: Correlation Results

\begin{tabular}{|l|l|l|l|}
\hline \multicolumn{1}{|c|}{} & DJIW & DJID & DJIE \\
\hline DJIW & 1.000 & & \\
\hline DJID & $0.970^{* * *}$ & 1.000 & \\
\hline DJIE & $0.597^{* * *}$ & $0.542^{* * *}$ & 1.000 \\
\hline
\end{tabular}

Notes: ${ }^{* * *}$ indicates a statistically significant correlation at the $1 \%$ significance level. 
We start the empirical analysis by utilizing linear unit root tests (the ADF and Phillips-Perron (PP) to obtain the integration order of the series. The linear unit root test results in Table 3 show that the null hypothesis of unit root cannot be rejected in levels. However, we reject the null hypothesis at the $1 \%$ significance level in the first differences of the series. The ADF and PP unit root test results are consistent with weak-form efficiency in global Islamic stock markets because the results indicate that the Islamic stock market indices exhibit random walk like behavior, which is consistent with weak-form efficiency.

Table 3: Linear Unit Root Tests Results

\begin{tabular}{|c|c|c|c|c|}
\hline \multirow[t]{2}{*}{ Indices } & \multicolumn{2}{|c|}{$\mathrm{ADF}$} & \multicolumn{2}{|c|}{ PP } \\
\hline & Level & $\begin{array}{l}\text { First } \\
\text { Differences }\end{array}$ & Level & $\begin{array}{l}\text { First } \\
\text { Differences }\end{array}$ \\
\hline DJIW & $\begin{array}{l}-1.353(6) \\
{[0.606]}\end{array}$ & $\begin{array}{l}-34.055^{* * *}(5) \\
{[0.000]}\end{array}$ & $\begin{array}{l}-1.362 \\
{[0.602]}\end{array}$ & $\begin{array}{l}-68.531^{* * *} \\
{[0.000]}\end{array}$ \\
\hline DJID & $\begin{array}{l}-1.210(28) \\
{[0.672]}\end{array}$ & $\begin{array}{l}-14.263^{* * *} \\
(27) \\
{[0.003]}\end{array}$ & $\begin{array}{l}-1.282 \\
{[0.640]}\end{array}$ & $\begin{array}{l}-71.868 \text { *** } \\
{[0.005]}\end{array}$ \\
\hline DJIE & $\begin{array}{l}-1.900(29) \\
{[0.332]}\end{array}$ & $\begin{array}{l}-12.355^{* * *} \\
(33) \\
{[0.000]}\end{array}$ & $\begin{array}{l}-1.629 \\
{[0.467]}\end{array}$ & $\begin{array}{l}-65.320 * * * \\
{[0.000]}\end{array}$ \\
\hline
\end{tabular}

Notes: The figures in parentheses are the optimal number of lags selected according to the AIC. The figures in square brackets show the probability (p-values) of rejecting the null hypothesis (non-stationarity). ${ }^{* * *}$, $* *$, and ${ }^{*}$ indicate that the series in question is stationary at the $1 \%, 5 \%$, and $10 \%$ significance level, respectively.

As mentioned above, conventional unit root tests have been extensively argued because they exhibit low performance rejecting the null of nonstationarity when the series exhibits nonlinear properties. Hence, we employ an LR test proposed by Di Sanzo (2009) to ascertain whether Islamic stock markets show regime-switching properties. We also calculate the conventional LR test to detect whether the MS-ADF model better describes the data than the linear ADF model. However, following conventional procedures for testing the Markov-Switching model is complicated because the transition probabilities in the MS-ADF model are not defined in the linear ADF model. Therefore, the asymptotic distribution for the test does not have standard $\chi^{2}$-distribution. To handle this problem, we use upper bond $p$ values suggested by Davies (1987). 
We present the LR test results in Table 4. As in the linear ADF test, we choose the optimal lag length according to AIC in the MS-ADF test, and the null hypothesis of the linear ADF model is tested against the alternative of the two-state MS-ADF model in the LR test. The results in Table 4 indicate that the optimal lag length is 6 for DJIW and DJID and is 2 for DJIE. However, the null hypothesis of no regime-switching is strongly rejected for all Islamic stock indices according to Davies and Di Sanzo $p$-values. Hence, the two-state MS-ADF test seems to be more convenient for examining the stochastic properties of Islamic stock markets.

Table 4: LR Test Results

\begin{tabular}{|l|l|l|l|l|l|l|}
\hline Indices & Lags & $\begin{array}{l}\text { Log-Likelihood } \\
\left(\mathrm{H}_{0}\right)\end{array}$ & $\begin{array}{l}\text { Log-Likelihood } \\
\left(\mathrm{H}_{\mathrm{A}}\right)\end{array}$ & $\begin{array}{l}\chi^{2} \\
p \text {-value }\end{array}$ & $\begin{array}{l}\text { Davies } \\
p \text {-value }\end{array}$ & $\begin{array}{l}\text { Di Sanzo } \\
p \text {-value }\end{array}$ \\
\hline DJIW & 6 & 20135.73 & 21116.55 & 0.000 & 0.000 & $\mathbf{0 . 0 0 0}$ \\
\hline DJID & 6 & 19858.51 & 20929.70 & 0.000 & 0.000 & $\mathbf{0 . 0 0 0}$ \\
\hline DJIE & $\mathbf{2}$ & $\mathbf{1 8 6 9 1 . 2 6}$ & $\mathbf{1 9 6 8 1 . 4 7}$ & $\mathbf{0 . 0 0 0}$ & $\mathbf{0 . 0 0 0}$ & $\mathbf{0 . 0 0 0}$ \\
\hline
\end{tabular}

After confirming the existence of regime-switching in the global Islamic stock markets, we estimate the MS-ADF model. The classifying of regimes is a crucial task in the Markov-Switching model. We follow the literature and consider both the smoothed transition probabilities and estimated coefficients in identifying the regimes. The smoothed transition probabilities for both stock market indices presented in Figure 1 indicate that the first regime corresponds to high volatility periods in the global financial markets (such as 1996-97 South Asian crisis, 1998 Russian crisis, 2000 dot-com crisis, 2001 Enron scandal, and 2007-2008 the global financial crisis). Besides, the standard deviations of the first regime are higher than the second regime $\left(\sigma_{1}>\sigma_{2}\right)$ and hence we identify the first regime as "high volatility" whereas the second regime is called "low volatility" regime.

We present the MS-ADF test results for DJIW in Table 5. The estimated transition probabilities in Table 5 show that the low volatility regime is more permanent than the high volatility regime. In that respect, the probability of staying in a low (high) volatility regime at time $t$ when the series is also in a low (high) volatility regime at time $t-1$ is $98.3 \%$ (96.7\%). The mean duration of low and high volatility regimes is approximately 2.5 and 1.2 months, respectively.

Note that we cannot reject a unit root in the DJIW according to linear unit root tests. However, the results in Table 5 show a distinct picture since the simulated $p$-values suggest rejecting the null hypothesis of unit root at 
the $1 \%$ level in the high volatility regime ( $p$-values is 0.003 ) whereas it cannot be rejected at conventional significance level in the low volatility regime ( $p$-values is 0.122 ). These results imply that DJIW is stationary only in the high volatility regime and hence the weak-form efficient market hypothesis cannot be validated for this regime because stock prices exhibit mean-reverting properties. These results are coherent with those in the existing literature (e.g. Alvarez-Diaz et al., 2014; Jawadi et al., 2015) that provide evidence against EMH in Islamic financial markets. However, we cannot reject the null hypothesis in the low volatility regime and hence stock prices tend to conform to random walk behavior in the second regime. This result provides evidence in favor of EMH in the low volatility regime. Overall, the regime-dependent unit root test results show that market efficiency is not valid all the time and it varies over the regimes; as such, these results lend support to the Adaptive Market Hypothesis.

Table 5: MS-ADF test results for DJIW

\begin{tabular}{|c|c|c|c|c|c|c|c|c|c|c|}
\hline \multicolumn{11}{|c|}{ Panel A: Coefficients } \\
\hline \multirow[t]{2}{*}{ Parameters } & \multicolumn{5}{|c|}{ High Volatility Regime } & \multicolumn{5}{|c|}{ Low Volatility Regime } \\
\hline & \multicolumn{2}{|c|}{ Coefficients } & Std. error & \multicolumn{2}{|l|}{$p$-value } & \multicolumn{2}{|c|}{ Coefficients } & \multicolumn{2}{|c|}{ Std. error } & $p$-value \\
\hline$a$ & \multicolumn{2}{|c|}{0.02419} & $(0.0086)$ & & & \multicolumn{2}{|c|}{0.0029} & \multicolumn{2}{|c|}{$(0.0017)$} & \\
\hline$\alpha$ [p-value $]$ & \multicolumn{2}{|c|}{-0.0033} & $(0.0011)$ & \multicolumn{2}{|l|}{$[0.003]$} & \multicolumn{2}{|c|}{-0.0002} & \multicolumn{2}{|c|}{$(0.0002)$} & [0.122] \\
\hline$\sigma$ & \multicolumn{2}{|c|}{0.0144} & $(0.0003)$ & & & \multicolumn{2}{|c|}{0.0058} & \multicolumn{2}{|c|}{$(0.0001)$} & \\
\hline$\Sigma \rho_{i}$ & \multicolumn{5}{|c|}{-0.0577} & \multicolumn{5}{|c|}{0.01556} \\
\hline \multicolumn{11}{|c|}{ Panel B: Transition Matrix } \\
\hline & & & \multicolumn{4}{|c|}{ Regime 1} & \multicolumn{4}{|c|}{ Regime 2} \\
\hline \multicolumn{3}{|l|}{ Regime 1} & \multicolumn{4}{|l|}{0.983} & \multicolumn{4}{|c|}{0.033} \\
\hline \multicolumn{3}{|l|}{ Regime 2} & \multicolumn{2}{|l|}{0.017} & & & \multicolumn{4}{|c|}{0.967} \\
\hline \multicolumn{11}{|c|}{ Panel C: Regime Properties } \\
\hline & & \multicolumn{3}{|c|}{ Observation Number } & \multicolumn{4}{|c|}{ Probability } & \multicolumn{2}{|c|}{ Duration } \\
\hline \multicolumn{2}{|l|}{ Regime 1} & 2035 & & & 0.3 & 25 & & & 37.00 & \\
\hline Regime 2 & & 4220 & & & 0.6 & 74 & & & 75.36 & \\
\hline Panel D: Like & ihooc & ad Infor & nation Crite & & & & & & & \\
\hline & & & MS-ADF & & & & & ADF & & \\
\hline AIC & & & -6.731 & & & & & -6.43 & & \\
\hline BIC & & & -6.710 & & & & & -6.42 & & \\
\hline HQ & & & -6.738 & & & & & -6.43 & 32 & \\
\hline
\end{tabular}


Note: The simulated $p$-value is in square brackets. $\sigma$ shows the standard error of the regression.

We present the MS-ADF model results for DJID in Table 6. The results in the bottom panel of Table 6 show the model information criteria and all model information criteria suggest the MS-ADF model better characterizes data than the linear ADF model. We find that the low volatility regime is more persistent than the high volatility regime according to the smoothed transition probabilities. The probability of remaining in a low volatility regime at time $t$ when the series is also in a low volatility regime at time $t-1$ is $98.5 \%$. On the other hand, the probability of remaining in a high volatility regime at time $t$ when the series is also in a high volatility regime at time $t-1$ is $96.3 \%$. The mean duration of low and high volatility regimes is approximately 2.8 and 1.2 months, respectively.

The simulated $p$-values indicate that the time series properties of DJID change over the regimes and the null hypothesis of a unit root can be rejected only in the high volatility regime. However, the null hypothesis cannot be rejected at conventional levels in the low volatility regime. These results have implications for market efficiency because the linear unit root test results provide strong evidence in favor of nonstationarity. The rejection of the null hypothesis in the low volatility regime indicates that the DJID index exhibits a mean-reversion in the high volatility regime and this result is not consistent with the conventional weak form of the EMH. On the other hand, the DJID index has random walk properties in the low volatility regime, and this finding consistent with the EMH. Overall, these results indicate that the AMH better describes the DJID index than the EMH because we find that the DJID stock market is not always efficient.

Table 6: MS-ADF test results for DJID

\begin{tabular}{|l|l|l|l|l|l|l|}
\hline \multicolumn{2}{|l|}{ Panel A: Coefficients } \\
\hline \multirow{2}{*}{ Parameters } & \multicolumn{5}{l|l|}{ High Volatility Regime } & \multicolumn{2}{l|}{ Low Volatility Regime } \\
\hline & Coefficients & Std. error & p-value & Coefficients & Std. error & $p$-value \\
\hline$a$ & 0.0245 & $(0.0092)$ & & 0.0025 & $(0.0019)$ & \\
\hline$\alpha$ [p-value] & -0.0037 & $(0.0013)$ & {$[0.038]$} & -0.0002 & $(0.0002)$ & [0.175] \\
\hline$\sigma$ & 0.0159 & $(0.0004)$ & & 0.0061 & $(0.0001)$ & \\
\hline$\Sigma \rho_{i}$ & -0.1344 & & & -0.0095 & & \\
\hline
\end{tabular}


Mehmet Fatih BUĞAN, Emrah İsmail ÇEVİK \& Nüket KIRCI ÇEVIK \& D. Çağrı YILDIRIM

\begin{tabular}{|c|c|c|c|c|c|}
\hline \multicolumn{6}{|c|}{ Panel B: Transition Matrix } \\
\hline & & \multicolumn{2}{|l|}{ Regime 1} & \multicolumn{2}{|l|}{ Regime 2} \\
\hline \multicolumn{2}{|l|}{ Regime 1} & \multicolumn{2}{|l|}{0.985} & \multicolumn{2}{|l|}{0.037} \\
\hline \multicolumn{2}{|l|}{ Regime 2} & \multicolumn{2}{|l|}{0.015} & \multicolumn{2}{|l|}{0.963} \\
\hline \multicolumn{6}{|c|}{ Panel C: Regime Properties } \\
\hline & \multicolumn{2}{|c|}{ Observation Number } & \multicolumn{2}{|l|}{ Probability } & Duration \\
\hline Regime 1 & \multicolumn{2}{|l|}{1770} & \multicolumn{2}{|l|}{0.283} & 37.41 \\
\hline Regime 2 & \multicolumn{2}{|l|}{4485} & \multicolumn{2}{|l|}{0.717} & 86.25 \\
\hline \multicolumn{6}{|c|}{ Panel D: Likelihood and Information Criteria } \\
\hline & & \multicolumn{2}{|l|}{ MS-ADF } & \multicolumn{2}{|l|}{ ADF } \\
\hline AIC & & \multicolumn{2}{|l|}{-6.685} & \multicolumn{2}{|c|}{-6.347} \\
\hline BIC & & \multicolumn{2}{|l|}{-6.664} & \multicolumn{2}{|c|}{-6.338} \\
\hline HQ & & \multicolumn{2}{|l|}{-6.678} & \multicolumn{2}{|c|}{-6.344} \\
\hline
\end{tabular}

Note: The simulated $p$-value is in square brackets. $\sigma$ shows the standard error of the regression.

Finally, we present the MS-ADF model results for DJIE in Table 7. As in the other model results, we determine strong evidence in favor of the MSADF model rather than the linear ADF model according to model information criteria. The smoothed transition probabilities suggest that the high volatile regime is more persistent than the low volatility regime. In this manner, the probability of remaining in a low volatility regime at time $t$ when the series is also in a low volatility regime at time $t-1$ is $97.3 \%$. On the other hand, the probability of remaining in a high volatility regime at time $t$ when the series is also in a high volatility regime at time $t-1$ is $98.9 \%$. The mean duration of low and high volatility regimes is approximately 11.8 and 3.6 months, respectively.

Even if the null hypothesis of nonstationarity cannot be rejected according to conventional unit root tests, the MS-ADF test results tell us a different story. Because the simulated $p$-values indicate that while the null hypothesis is rejected at a $1 \%$ significance level in the high volatility regime, we can reject it at $10 \%$ significance level in the low volatility regime. These results imply that DJIE is stationary in both regimes and hence the weakform of the efficient market hypothesis is not validated over both regimes because stock prices exhibit mean-reverting properties. These results are consistent with those in the existing literature (e.g. Alvarez-Diaz et al., 2014; Jawadi et al., 2015) that provide evidence against EMH in the Islamic 
financial markets. These results are significant because we find deviations from market efficiency in Dow Jones Islamic World and Developed market in at least one regime and hence we can say that these two stock markets are in line with the AMH. On the other hand, neither EMH nor AMH seems to be valid for the Dow Jones Islamic Emerging Market. Furthermore, Ali et al. (2018) found that developed Islamic markets are more efficient than emerging Islamic markets.

Table 7: MS-ADF test results for DJIE

\begin{tabular}{|c|c|c|c|c|c|c|}
\hline \multicolumn{7}{|c|}{ Panel A: Coefficients } \\
\hline \multirow[t]{2}{*}{ Parameters } & \multicolumn{3}{|c|}{ High Volatility Regime } & \multicolumn{3}{|c|}{ Low Volatility Regime } \\
\hline & Coefficients & Std. error & $p$-value & Coefficients & Std. error & $p$-value \\
\hline$a$ & 0.0216 & $(0.0083)$ & & 0.0060 & $(0.0032)$ & \\
\hline$\alpha$ [p-value] & -0.0031 & $(0.0011)$ & {$[0.000]$} & -0.0007 & $(0.0004)$ & {$[0.060]$} \\
\hline$\sigma$ & 0.0182 & $(0.0001)$ & & 0.0074 & $(0.0001)$ & \\
\hline$\Sigma \rho_{i}$ & \multicolumn{3}{|l|}{0.194} & \multicolumn{3}{|l|}{0.146} \\
\hline \multicolumn{7}{|c|}{ Panel B: Transition Matrix } \\
\hline & \multicolumn{3}{|c|}{ Regime 1} & \multicolumn{2}{|c|}{ Regime 2} & \\
\hline \multicolumn{2}{|l|}{ Regime 1} & \multicolumn{2}{|c|}{0.989} & \multicolumn{2}{|c|}{0.022} & \\
\hline \multicolumn{2}{|l|}{ Regime 2} & \multicolumn{2}{|c|}{0.011} & \multicolumn{2}{|c|}{0.973} & \\
\hline \multicolumn{7}{|c|}{ Panel C: Regime Properties } \\
\hline & \multicolumn{2}{|c|}{$\begin{array}{l}\text { Observation } \\
\text { Number }\end{array}$} & \multicolumn{2}{|c|}{ Probability } & \multicolumn{2}{|l|}{ Duration } \\
\hline Regime 1 & \multicolumn{2}{|l|}{4186} & \multicolumn{2}{|l|}{0.668} & \multicolumn{2}{|l|}{110.16} \\
\hline Regime 2 & \multicolumn{2}{|l|}{2073} & \multicolumn{2}{|l|}{0.331} & \multicolumn{2}{|l|}{56.03} \\
\hline \multicolumn{7}{|c|}{ Panel D: Likelihood and Information Criteria } \\
\hline & & \multicolumn{2}{|c|}{ MS-ADF } & \multicolumn{2}{|c|}{ ADF } & \\
\hline AIC & & 285 & & & 71 & \\
\hline BIC & & 272 & & & & \\
\hline HQ & & 280 & & & 69 & \\
\hline
\end{tabular}

Note: The simulated $p$-value is in square brackets. $\sigma$ shows the standard error of the regression.

The smoothed transition probabilities for the global Islamic markets are given in Figure 1. The results in Figure 1 show that the high and low volatility regimes are very similar for three global Islamic stock markets. Furthermore, the smoothed transition probabilities for the first regime 
corresponds to the high volatile periods in the global financial markets (such as the 1996-97 South Asian crisis, 1998 Russian crisis, 2000 dot-com crisis, 2001 Enron scandal, and 2007-2008 the global financial crisis).

Figure 1: The Smoothed Transition Probabilities for High Volatility Regime

(a) DJIW

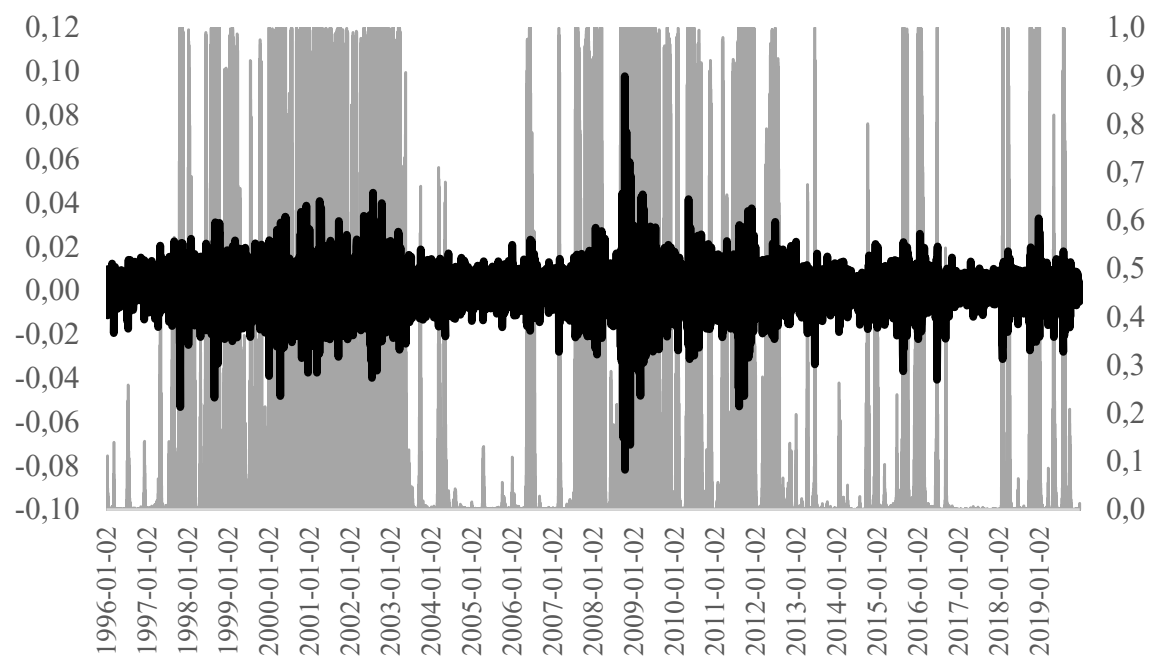

Note: The shaded areas are transition probabilities.

(b) DJID

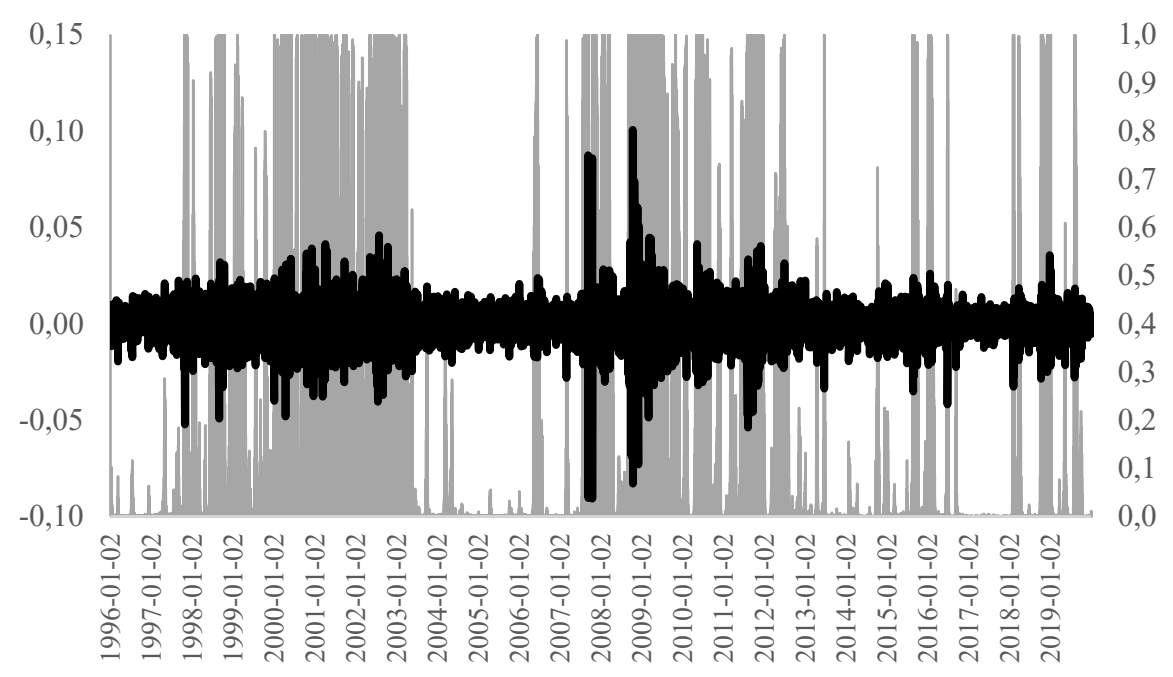

Note: The shaded areas are transition probabilities. 
(c) DJIE

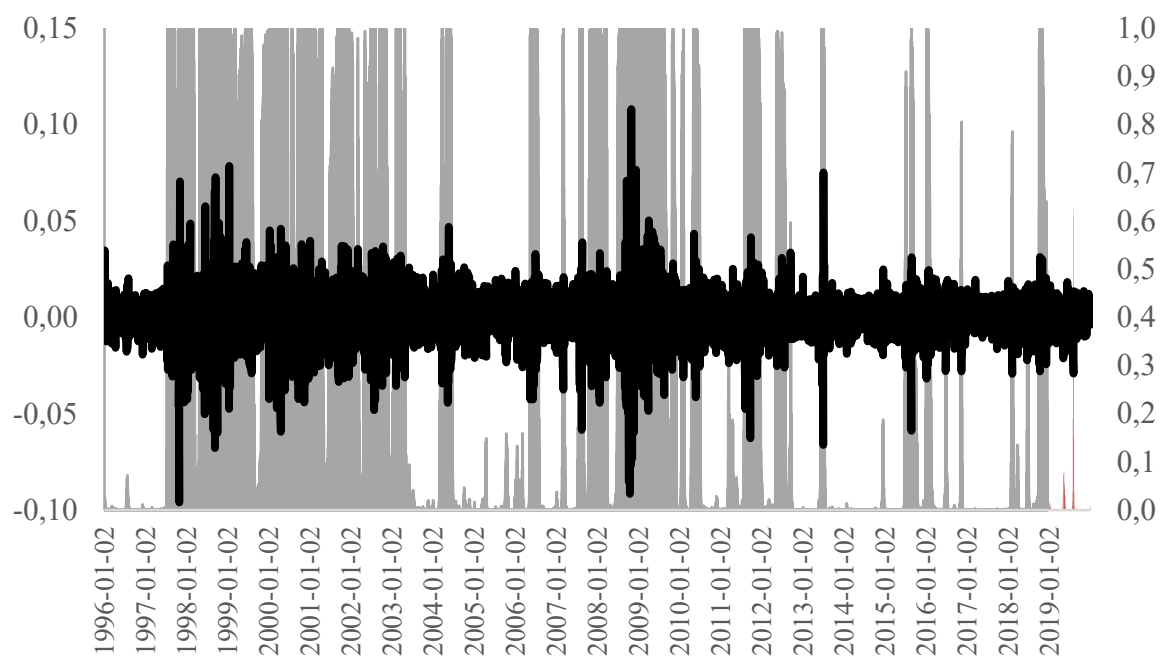

Note: The shaded areas are transition probabilities.

\section{Conclusions}

The Efficient Market Hypothesis proposed by Fama (1970) has been extensively investigated in the literature because it is a cornerstone of standard finance and investor behavior. Therefore, there has been literature that focuses on investigating the EMH specifically in the conventional stock markets. However, the empirical results show that there is no consensus for the EMH in the literature because some studies have documented evidence in favor of EMH, while some studies deviate from the EMH.

Deviations from the EMH raised some doubts on the assumptions of the EMH, specifically the assumption of rational investor behavior. Moreover, several studies in the field of psychology and experimental economics focused on the limited rationality of investors; consequently, many biases and heuristics have been identified. At this point, the Adaptive Market Hypothesis (AMH) suggested by Lo (2004) has provided a reasonable bridge between EMH and behavioral finance theory. Specifically, Lo (2004 and 2005) suggested that the EMH cannot be valid all time, as such market efficiency varies over time according to stock market cycles (such as bearish and bullish regimes).

Although there is well-documented literature that examines the presence of EMH or AMH for the conventional stock markets, a limited number of studies focus on the Islamic stock markets. Because market efficiency is related to a well-functioning market, it is of great importance for 
the efficient allocation of resources and also providing sustainable economic growth. Market efficiency is not only important for conventional stock markets but also for the Islamic stock market because the Islamic stock markets are gaining prominence. Hence, the motivation for investigating the efficiency of Islamic stock markets.

This study aims to examine nonlinearity and nonstationary in the global Islamic stock markets where the focus is on developed and emerging markets Islamic stock markets. We first use linear unit root tests and the null hypothesis of nonstationary cannot be rejected. Therefore, the linear ADF test result provides evidence in favor of EMH in Islamic stock markets. However, linearity test results show the existence of regime-switching properties in all Islamic stock market indices and the MS-ADF test confirms regime-dependence. As such, the MS-ADF test provides a better characterization of the behavior of price dynamics in the Islamic stock markets. The two-state regimes are identified as high volatility and low volatility regime. Moreover, MS-ADF test results indicate that the null hypothesis of a unit root can be rejected in the high volatility regime for the world and developed Islamic stock markets. However, we find evidence in favor of the random walk process for the low volatility regime. These findings indicate that the EMH is valid only in the low volatility regime for the world and developed Islamic stock markets. Finally, the Dow Jones Islamic Emerging index is found to be stationary over both regimes and this result confirms that the emerging Islamic market is not weak-form efficient. The evidence in favor of stationarity, specifically in the high volatility regime, can be explained by Shariah screening that is prone to making Islamic stock markets more stable and predictable specifically in high volatility regimes. These findings are consistent with empirical results documented in Ali et al. (2018) who indicate that the Islamic stock markets are more resistant to speculative activity than their conventional counterparts.

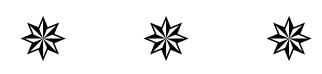

\section{BIBLIOGRAPHY}

ALI, S., SHAHZAD, S. J. H., RAZA, N., \& Al-YAHYAEE, K. H. (2018). Stock market efficiency: A comparative analysis of Islamic and conventional stock markets. Physica A: Statistical Mechanics and Its Applications, 503, 139153.

Al-KHAZALI, O., \& MIRZAEI, A. (2017). Stock market anomalies, market efficiency and the adaptive market hypothesis: Evidence from Islamic stock indices. Journal of International Financial Markets, Institutions 
and Money, 51, 190-208.

ALOUI, C., HKIRI, B., LAU, C. K. M., \& YAROVAYA, L. (2016). Investors' sentiment and US Islamic and conventional indexes nexus: A timefrequency analysis. Finance Research Letters, 19, 54-59.

ALVAREZ-DÍAZ, M., HAMMOUDEH, S., \& GUPTA, R. (2014). Detecting predictable non-linear dynamics in Dow Jones Islamic Market and Dow Jones Industrial Average indices using nonparametric regressions. The North American Journal of Economics and Finance, 29, 22-35.

ALVAREZ-RAMIREZ, J., RODRIGUEZ, E., \& ESPINOSA-PAREDES, G. (2012). Is the US stock market becoming weakly efficient over time? Evidence from 80-year-long data. Physica A: Statistical Mechanics and Its Applications, 391(22), 5643-5647.

BOUOIYOUR, J., SELMI, R., \& WOHAR, M. E. (2018). Are Islamic stock markets efficient? A multifractal detrended fluctuation analysis. Finance Research Letters, 26, 100-105.

CARRASCO, M., HU, L., \& PLOBERGER, W. (2009). Optimal test for Markov switching. Econometrica, 82(2), 765-784.

CEVIK, E. I., \& BUGAN, M. F. (2018). Regime-dependent relation between Islamic and conventional financial markets. Borsa Istanbul Review, 18 (2), 114-121.

CEVIK, E. I., \& DIBOOGLU, S. (2013). Persistence and non-linearity in US unemployment: A regime-switching approach. Economic Systems, 37(1), 61-68.

CEVIK, E. I., YILDIRIM, D. Ç., \& DIBOOGLU, S. (2020). Renewable and nonrenewable energy consumption and economic growth in the US: A Markov-Switching VAR analysis. Energy \& Environment, 0958305X2094403. doi:10.1177/0958305x20944035

CHARFEDDINE, L., KHEDIRI, K. B., AYE, G. C., \& GUPTA, R. (2018). Timevarying efficiency of developed and emerging bond markets: Evidence from long-spans of historical data. Physica A: Statistical Mechanics and Its Applications, 505, 632-647.

Charles, A., Darné, O., \& Kim, J. H. (2012). Exchange-rate return predictability and the adaptive markets hypothesis: Evidence from major foreign exchange rates. Journal of International Money and Finance, 31(6), 1607-1626.

CHARLES, A., DARNÉ, O., \& KIM, J. H. (2017). Adaptive markets hypothesis for 
Mehmet Fatih BUĞAN, Emrah İsmail ÇEVİK \& Nüket KIRCI ÇEVIK \& D. Çağrı YILDIRIM

Islamic stock indices: Evidence from Dow Jones size and sectorindices. International Economics, 151, 100-112.

CHO, J., \& WHITE, H. (2007). Testing for regime switching. Econometrica 75, 1671-1720.

DAVIES, R. B. (1987). Hypothesis testing when the nuisance parameter is present only under the alternative. Biometrika 74:33-43.

Di SANZO, S. (2009). Testing for linearity in Markov switching models: a bootstrap approach. Statistical Methods and Applications, 18: 153-168.

DICKEY, D. A., \& FULLER, W. A. (1979). Distribution of the estimators for autoregressive time series with a unit root. Journal of the American Statistical Association, 74, 427-431.

FAMA, E. F. (1970). Efficient capital markets: A review of theory and empirical work. The Journal of Finance, 25(2), 383-417.

FAMA, E. F., \& FRENCH, K. R. (1988a). Dividend yields and expected stock returns. Journal of Financial Economics, 22: 3-25.

GARCIA, R. (1998). Asymptotic null distribution of the likelihood ratio test in Markov switching models. International Economic Review 39:763-788.

GHAZANI, M. M., \& EBRAHIMI, S. B. (2019). Testing the adaptive market hypothesis as an evolutionary perspective on market efficiency: Evidence from the crude oil prices. Finance Research Letters, 30, 6068.

GUPTA, R., HAMMOUDEH, S., SIMO-KENGNE, B. D., \& SARAFRAZI, S. (2014). Can the Sharia-based Islamic stock market returns be forecasted using large number of predictors and models? Applied Financial Economics, 24(17), 1147-1157.

HALL, S. G., PSARADAKIS, Z., \& SOLA, M. (1999). Detecting periodically collapsing bubbles: a Markov-Switching unit root test. Journal of Applied Econometrics, 14, 143-154.

HANSEN, B. (1992). The likelihood ratio test under non-standard conditions: testing the Markov switching model of GNP. Journal of Applied Econometrics 7,61-82.

HIREMATH, G. S., \& KUMARI, J. (2014). Stock returns predictability and the adaptive market hypothesis in emerging markets: Evidence from India. SpringerPlus, 3(1), 428.

HOLMES, M. J. (2010). Are Asia-Pacific real exchange rates stationary? A regime-switching perspective. Pacific Economic Review, 15(2), 189- 
203.

JAWADI, F., JAWADI, N., \& CHEFFOU, A. I. (2015). Are Islamic stock markets efficient? A time-series analysis. Applied Economics, 47(16), 16861697.

KANAS, A., \& GENIUS, M. (2005). Regime (non)stationarity in the US/UK real exchange rate. Economics Letters, 87, 407-413.

KHEDIRI, K. B., \& CHARFEDDINE, L. (2015). Evolving efficiency of spot and futures energy markets: A rolling sample approach. Journal of Behavioral and Experimental Finance, 6, 67-79.

KHURSHEED, A., NAEEM, M., AHMED, S., \& MUSTAFA, F. (2020). Adaptive market hypothesis: An empirical analysis of time -varying market efficiency of cryptocurrencies. Cogent Economics \& Finance, 8(1), 1719574.

LO, A. W. (2004). The Adaptive Markets Hypothesis. The Journal of Portfolio Management, 30(5), 15-29.

LO, A. W. (2005). Reconciling efficient markets with behavioral finance: The adaptive markets hypothesis. Journal of Investment Consulting, 7(2), 21-44.

LO, A.W., \& MacKinlay A. C. (1988). Stock market prices do not follow random walks: evidence from a simple specification test. Review of Financial Studies, 1: 41-66.

MISHRA, A., MISHRA, V., \& SMYTH, R. (2015). The random-walk hypothesis on the Indian Stock Market. Emerging Markets Finance and Trade, 51(5), 879-892.

NASR, A. B., LUX, T., AJMI, A. N., \& GUPTA, R. (2016). Forecasting the Volatility of the Dow Jones Islamic Stock Market Index: Long Memory vs. Regime Switching. International Review of Economics and Finance, 45, 559-71.

NELSON, C. R., PIGER, J. \& ZIVOT E. (2001). Markov regime switching and unit-root tests. Journal of Business and Economic Statistics, 19(4), 404415.

RODRIGUEZ, E., AGUILAR-CORNEJO, M., FEMAT, R., \& ALVAREZ-RAMIREZ, J. (2014). US stock market efficiency over weekly, monthly, quarterly and yearly time scales. Physica A: Statistical Mechanics and Its Applications, 413, 554-564.

SHAHID, M. N., JEHANZEB, M., ABBAS, A., ZUBAIR, A., \& AKBAR, M. A. H. (2019a). Predictability of precious metals and adaptive market hypothesis. International Journal of Emerging Markets, ahead-of- 
Mehmet Fatih BUĞAN, Emrah İsmail ÇEVİK \& Nüket KIRCI ÇEVIK \& D. Çağrı YILDIRIM

print(ahead-of-print).

SHAHID, M. N., SATTAR, A., AFTAB, F., SAEED, A., \& ABBAS, A. (2019b). Month of Ramadan effect swings and market becomes adaptive: A firm level evidence through Islamic calendar. Journal of Islamic Marketing, ahead-of-print(ahead-of-print). https://doi.org/10.1108/JIMA-122017-0140

SHI, S. (2013). Specification sensitivities in the Markov-switching unit root test for bubbles. Empirical Economics 45, 697-713.

SIMON, H. A. (1955). A Behavioral Model of Rational Choice. The Quarterly Journal of Economics, 69(1), 99-118.

URQUHART, A., \& HUDSON, R. (2013). Efficient or adaptive markets? Evidence from major stock markets using very long run historic data. International Review of Financial Analysis, 28, 130-142.

XIONG, X., MENG, Y., LI, X., \& SHEN, D. (2019). An empirical analysis of the Adaptive Market Hypothesis with calendar effects: Evidence from China. Finance Research Letters, 31.

YÜCEL, A. G., \& KÖSEOĞLU, A. (2020). Do participation banks contribute to economic growth? Time-series evidence from Turkey. Bilimname, 2020(42), 155-180.

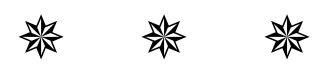




\title{
GLOBAL İSLAMİ PAY PIYYASALARINDA ADAPTİF PIYYASA HIPPOTEZININN TEST EDİLMESI: MARKOV-SWITCHING ADF TESTİ
}

\author{
Mehmet Fatih BUĞANa \\ Nüket KIRCI ÇEVIK ${ }^{c}$
}

Emrah İsmail ÇEVIK ${ }^{\mathrm{b}}$

Durmuş Çağrı YILDIRIM ${ }^{\mathrm{d}}$

\begin{abstract}
Geniş Öz
Etkin Piyasa Hipotezi, piyasaya her gelen yeni bilginin hisse senedi fiyatlarına anında yansıyacağı, böylelikle yatırımcıların anormal getiri elde edemeyeceklerini varsayarak bilgi akışının önemini vurgulamaktadır. Etkin piyasa hipotezinin zayıf form, yarı güçlü form ve güçlü form olmak üzere üç farklı formu bulunmaktadır. Bu sınıflandırma, piyasadaki bilgi türlerine göre oluşturulmuştur. Buna göre, zayıf formda piyasa etkinliğine göre, hisse senedi fiyatları geçmiş fiyatların içerdiği tüm bilgileri içerir. Yarı güçlü piyasa etkinliği ile fiyatlar, halka açı tüm bilgileri yansıtırken etkin piyasa hipotezinin güçlü formda piyasa etkinliğine göre fiyatlar halka açlk olan bilgilerin yanısıra özel bilgileri de (insider trading) yansıtır.

Etkin piyasa hipotezinin en önemli temel varsayımlarından birisi yatırımcıların yatırım kararlarında rasyonel hareket etmeleridir. Ancak, yapılan çok sayıda çalışmada, etkin piyasa hipotezi ile çelişen biçimde pay piyasalarındaki anomaliler, bazen getirilerin öngörülebilirliği ve yatırımcıların sınırlı rasyonelliği lehine kanıtlar bulunmaktadır. Ayrıca, psikoloji ve deneysel iktisat alanındaki çeşitli çalışmalar yatırımcıların rasyonaliteden sapmalarına odaklanmış ve sonuç olarak birçok önyargılı ve sezgisel davranış tespit edilmiştir. Bu sonuçlar, yatırımcıların yatırım kararlarında her zaman rasyonel davranmadıklarını ifade eden davranışsal
\end{abstract}

\footnotetext{
a Dr. Öğr. Üyesi, Gaziantep Üniversitesi, mfbugan@gantep.edu.tr

b Doç. Dr., Namık Kemal Üniversitesi, eicevik@nku.edu.tr

c Doç. Dr., Namık Kemal Üniversitesi, nkcevik@nku.edu.tr

d Prof. Dr., Namık Kemal Üniversitesi, dcyildirim@nku.edu.tr
} 
finans yaklaşımının canlanmasına yol açmıştır.

$\mathrm{Bu}$ noktada Lo (2004) tarafından önerilen ve etkin piyasa hipotezi ile davranışsal finans arasında bir köprü oluşturan Adaptif Piyasa Hipotezi öne çlkmaktadır. Lo (2004), Simon (1955) tarafından ortaya atılan sınırlı rasyonalite kavramını evrimsel bir bakış açısıyla yeniden ele almıștır. Bu bakış açısı, davranışların doğal seleksiyon (ayıklanma) tarafından evrimleştiğini ima eder. Burada doğal seleksiyon bireysel olarak optimalin altında kalabilen ancak popülasyon perspektifinden bakıldığında optimal olan davranışları gösterir. Buna göre, davranışlar yalın bir şekilde değil büyük ölçüde içeriğe bağlı olarak ele alınır. Lo (2005), adaptif piyasa hipotezinin temellerini şu şekilde ortaya koymuştur: (i) kişisel çıkar, bireysel davranışı karakterize eder; (ii) bireyler hatasız değildir; (iii) ortam rekabetçidir; iv) rekabet, bireyleri öğrenmeye ve uyum sağlamaya zorlar; (v) doğal seleksiyon, toplam piyasa sonuçlarını şekillendirir; (vi) evrim, nihai piyasa dinamiklerini belirler.

Finans alanındaki birçok model, yatırım stratejileri üzerinde önemli etkileri olan piyasa etkinliğine dayanmaktadır. Piyasa etkinliği sadece kaynak tahsisi perspektifi açısından önemli değildir, aynı zamanda yatırımcılar, akademisyenler ve düzenleyici otoriteler için de önemlidir ve konvansiyonel pay piyasaları için etkin piyasa hipotezini inceleyen detaylı bir literatür vardır. Bu bağlamda, son zamanlarda hızlı bir şekilde büyümekte olan ve dini duyarlılı̆̆ı olan yatırımcılar için alternatifler sunan İslami pay piyasaları için de piyasa etkinliğini incelemek ilgi çekici hale gelmiştir. İslami finans piyasaları için etkin piyasa hipotezinin araştırılmasını önemli kılan ek faktörler vardır çünkü İslami portföylerin oluşma şekli öngörülebilirliğe belli bir derecede katkıda bulunabilir. İki aşamalı şer'i taramanın düşük kaldıraçlı, likiditesi az, varlığa dayalı ve daha az çeşitlendirilmiş portföyler ile sonuçlandığı bilinmektedir. $\mathrm{Bu}$ da İslami pay senedi fiyatlarının öngörülebilirliğinin artmasını sağlamaktadır.

$\mathrm{Bu}$ çalışma, doğrusal olmayan birim kök testi (Markov Switching - ADF) kullanarak İslami borsalar için etkin ve adaptif piyasa hipotezlerini araştırmayı amaçlamaktadır. Literatürde yer alan çalışmalar birlikte ele alındığında, adaptif piyasa hipotezinin pay piyasalarının davranışını etkin piyasa hipotezinden daha iyi açıkladığı fikrini desteklemektedir.

Bu çalışmada Dow Jones Islamic World Index - (DJIW), Dow Jones Islamic Developed Index - (DJID) ve Dow Jones Islamic Emerging Index - (DJIE) olmak üzere, üç büyük İslami hisse senedi piyasası için DataStream'den elde edilen ve 1996-2019 dönemini kapsayan günlük veriler kullanılmıştır. 
Toplam gözlem sayısı 6261'dir.

$\mathrm{Bu}$ çalışma, özellikle gelişmiş ve gelişmekte olan İslami pay piyasalarını odağına alarak küresel İslami pay piyasalarındaki doğrusallık ve durağanlık durumlarını incelemeyi amaçlamaktadır. Öncelikle doğrusal birim kök testleri uygulanmış ve temel hipotez reddedilmemiştir. Bu nedenle, doğrusal ADF test sonucu İslami borsalarda etkin piyasa hipotezi lehine bulgulara ulaşılmıştır. Bununla beraber, doğrusallık testi sonuçları, tüm İslami borsa endekslerinde rejim değişim özelliklerinin varlığını göstermektedir ve Markov Switching - ADF testi rejime bağımlılı̆̆ doğrulamaktadır. Bu nedenle, Markov Switching - ADF testi İslami borsalarda fiyat dinamikleri davranışının daha iyi bir karakterizasyonunu sağlar. İki durumlu rejimler, yüksek volatilite ve düşük volatilite rejimi olarak tanımlanmaktadır. Ayrıca Markov Switching - ADF test sonuçları, global ve gelişmiş İslami borsalar için yüksek volatilite rejiminde birim kökün temel hipotezinin reddedilebileceğini göstermektedir. Ancak çalışmada, düşük volatilite rejimi için rassal yürüyüş süreci lehine kanıtlar bulunmuştur. Bu bulgular, etkin piyasa hipotezinin sadece global ve gelişmiş İslami borsalar için düşük volatilite rejiminde geçerli olduğunu göstermektedir. Son olarak, Dow Jones Gelişmekte Olan İslami piyasalar endeksinin her iki rejimde de durağan olduğu görülmüş ve bu sonuç, gelişmekte olan İslami piyasanın zayıf formda etkin olmadığını teyit etmiştir. Yüksek volatilite rejiminde durağanlığın lehine olan kanıtlar, İslami pay piyasalarının özellikle yüksek volatilite rejimlerinde daha istikrarlı ve öngörülebilir hale getirmeye meyilli olan Şer'i taramayla açıklanabilir. Bu bulgular, İslami borsaların spekülatif faaliyetlere konvansiyonel emsallerine göre daha dirençli olduğunu ifade eden Ali vd. (2018) ampirik sonuçları ile uyumludur.

Anahtar Kelimeler: İslami Ekonomi, Etkin Piyasa Hipotezi, Adaptif Piyasa Hipotezi, İslami Hisse Senedi Piyasaları, Markov-Switching ADF.

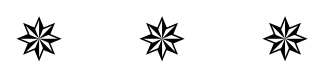

